\title{
Pátrania vo fantomatickom meste: Breslau retrodetektívok Mareka Krajewského
}

\section{Tomáš Horváth}

\author{
HORVÁTH, T.: Investigations in the Phantomatic City: Breslau in the \\ Retro Detective Novels of Marek Krajewski \\ SLOVENSKÁ LITERATÚRA, vol. 68, 2021, no. 3, pp. 337-347 \\ DOI: https://doi.org/10.31577/slovlit.2021.68.3.12 \\ ORCID ID: 0000-0001-5581-136X
}

\begin{abstract}
Key words: retro detective novel, geopoetics, representation of the city, toponyms, Breslau
\end{abstract}

\begin{abstract}
The article analyses the strategies Marek Krajewski employs to portray the city in his Breslau series. Owing to the compatibility of the text (signifier) and city (signified), it is relatively easy to represent the city in a literary text. The city is always already semiotically mediated and therefore prepared for its further semiotic processing in interpretation. Individual strategies of representation are always connected with certain layers of textual structures and are open to analysis by different areas of literary studies. The topographic representation of the city mediated by the layer of historical toponyms that form chains and paths crosses the boundary of the strictly internal textual structure and calls for geopoetics as analytical tool. The strategy of representing ordinariness via period objects for everyday use makes up for the layer of the retro genre. The narrative representation of the city-stories (and their matrixes) that form Krajewski's literary Breslau - predominantly constitutes the layer of the detective thriller genre. Combination of these strategies of representation of the city, delimited by a cross-section of the textual corpus of the Breslau series, forms Krajevski's specific generic representation of the city.
\end{abstract}

Klúčové slová: retrodetektívka, geopoetika, reprezentácia mesta, toponymá, Breslau 
(Albert Camus; motto ku Krajewského románu Koniec sveta $v$ Breslau) hl'adiska modernej semiotiky je reprezentácia mesta v literárnom texte pomerne dobre možná vd'aka kompatibilite textu (označujúceho) a mesta (označovaného). Tartuská semiotika kultúry nastolila perspektívu, z ktorej sa dá na mesto pozriet' ako na „sui generis ,semiotický objekt', a teda ako na osobitý text, ktorý komunikuje isté významy a je súčastou určitej komunikačnej situácie" (Żyłko 2007: 67). Mesto je znakovo sprostredkované, už predpripravené na svoje d'alšie znakové spracovanie, interpretovanie. Voči modelu mesta ako textu, do istej miery redukcionistickému, sa najmä v rámci kultúrneho obratu objavili výhrady (porovnaj Koschany 2013: 22) - mesto jeho obyvatelia nielen čítajú, ale primárne ide o „priestor žitého mesta“, v ktorom vykonávajú kultúrne praktiky (porovnaj Derdowska 2011: 44-46). Ked'že však v nasledujúcej analýze nepôjde celkom ani tak o mesto ako také, ale o literárnu reprezentáciu mesta, tento príspevok sa bude naozaj zaoberat' mestom čítaným a mestom „na čítanie“ - mestom v literárnych textoch. Predbežnou podmienkou, ktorá ulahčuje možnost' reprezentácie priestoru (vrátane mesta) v texte, je ,izomorfizmus problematiky priestoru a textu“, na ktorý upozorňuje Vladimir Toporov (Toporov 2002: 209): „text je priestorový (to jest má vlastnost' priestorovosti, je situovaný v ,reálnom priestore [...]), a zároveň priestor je textom (čiže priestor ako taký môže byt' chápaný ako komunikát)“ (Toporov 2002 : 207).

\section{Topografické ukotvenie reprezentácie mesta: geopoetika}

Jedným z úspešných príbehov na pol'skom literárnom trhu je príbeh spisovatel'a Mareka Krajewského (narodený 1966), pôvodným povolaním klasického filológa a vysokoškolského pedagóga. Po roku 1989 v podstate ustal čitatel'ský záujem o (či odkázanost'na) socialistickú detektívku (takzvaná ,powieść milicyjna“) s reáliami bývalého režimu. Hojne boli prekladaní západní autori, no postupne sa objavil čitatel'ský dopyt po podobne pútavých detektívkach a kriminálkach z domáceho prostredia (porovnaj Wróblewska 2014: 132). Ako prvý dosiahol v roku 1999 značný čitatel'ský úspech M. Krajewski debutovým románom Smrt'v Breslau (Śmierć w Breslau) napísaným v žánrovej forme retrodetektívky. Úspech breslauského cyklu M. Krajewského podnietil v Pol'sku celú vlnu retrodetektívok, odohrávajúcich sa poväčšine v medzivojnovom období, ako aj túžbu ich autorov „vytvorit' legendu pre vlastné mesto“ (Rybicka 2014: 336). Patria sem autori ako Marcin Wroński (lublinská séria), Paweł Jaszczuk (dej jeho románov sa odohráva v medzivojnovom L'vove), Konrad T. Lewandowski (so svojím varšavským cyklom), Tadeusz Cegielski (Varšava pät'desiatych rokov 2o. storočia), Izabela Żukowska (Gdańsk), Maryła Szymiczkowa (pseudonym Jacka Dehnela a Piotra Tarczyńského, dej románov sa odohráva v Krakove na prelome 19. a 20. storočia) a množstvo d'alších. Mestské detektívky zo súčasnosti píšu aj Tomasz Konatkowski či básnik Marcin Świetlicki. Hlavnou témou tohto príspevku bude interpretácia reprezentácie mesta Breslau (dnes Vroclav), jeho „literárnej geografie“v cykle retrodetektívok M. Krajewského. 
Žánrový podtyp retrodetektívky (v diferencii oproti historickej detektívke) 339 sa dá definovat' pomocou generačnej pamäti, ešte (alebo kedysi) pre spisovatela dosiahnutel'nej sprostredkovane cez žijúcich pamätníkov vo forme „oral history“ (retrodetektívka odohrávajúca sa vo svete generácie starých rodičov) a štylizovanej reprezentácie historického obdobia, ktoré prípadne môže stále skryto pôsobit' na aktuálnu prítomnost'. Kolektívna pamät totiž, ako ukazoval Maurice Halbwachs, generačne presahuje individuálnu pamät'- pamät' spoločenstva sa tiahne až „,tam, kam sahá pamět' skupin, ze kterých se společnost skládá“ (Halbwachs 2009: 128). Martyna Steckiewicz píše, že „svet retro je svet našich starých rodičov, ktorý často poznáme z rodinných rozprávaní, nepozbavených sentimentu“ (Steckiewicz 2014: 258). Retrodetektívka zväčša netematizuje konkrétne historické udalosti, ale historické obdobie je pozadím pre detektívnu zápletku. Retrodetektívky sú potom „vo vel'kej miere štylizáciou, predstavou o minulosti“ (Steckiewicz 2014:258). Na tvarovaní Krajewského medzivojnového Breslau sa v mnohom podielajú aj obrazy z populárnej kultúry o tomto období: autor využíva formulu detektívneho trileru drsnej školy s občasnými hororovými ingredienciami. Samotný Krajewski hovorí o tom, že píše noirové kriminálky (,„czarny kryminał“). Adam Mazurkiewicz ukazuje tiež vzt'ah súčasnej pol'skej detektívky k próze lokálnych „malých vlastí“ ako aktualizáciu jej formuly predovšetkým v smere „demystifikácie mýtov minulosti“ (Mazurkiewicz 2014:160). U Krajewského je to demystifikačný pohyb privolania fantóma-vytesnenej minulosti mesta. Môže však íst zároveň aj o vytváranie nových mýtov, napríklad mýtus „hriešneho mesta“, temného Breslau v Krajewského sérii.

Reprezentácia mesta v Krajewského románovej sérii je teda zakódovaná v istej žánrovej literárnej štruktúre, Breslau je vpísané do žánrovej štruktúry noirového mysteriózneho detektívneho trileru. Samotný Vroclavčan Krajewski sa vyjadril, že Breslau je v jeho románoch temný predovšetkým preto, lebo píše noirové detektívne trilery. (Ved' podobne temný je aj medzivojnový L'vov v Krajewského sérii o komisárovi Popielskom.) Tento žáner sa podiel'a predovšetkým na istom štýle reprezentácie mesta - nemecký Breslau v časoch Weimarskej republiky je temným, nebezpečným mestom s narastajúcim antisemitizmom, so stúpajúcou popularitou nacistov i zločinnostou, často reprezentovanýv noirovej štylizácii tieňov a nočného času (porovnaj Augustyn 2017:187-188) spolu s hammetovskou tmavou uličkou. Je to mesto brutálnych zločinov, organizovanej kriminality, sexuálnych deviantov, náboženských fanatikov (motivácia väčšiny vrážd v Krajewského románoch je podivný pokrútený náboženský fanatizmus) a temných uličiek, v ktorých striehnu násilie a smrt', mesto prekvitajúcej prostitúcie (luxusných verejných domov, no aj fiakristu ponúkajúceho svoju dcéru, či napríklad štyria mužskí prostitúti v námorníckych rovnošatách s vypichnutými očami a polámanými končatinami zavraždení v Prízrakoch v Breslau), mesto zapluvaných krčiem, ošarpaných domov a hlavne špinavých zadných dvorčekov, no aj kaviarní, reštaurácií (napríklad Piwnica Świdnicka, Biskupská pivnica), prepychových interiérov hornej vrstvy, v ktorých nezriedka prebiehajú sexuálne orgie. Je to hriešne mesto, nachádzajú sa v ňom tmavé bočné uličky, temné dvorčeky, krčmy, verejné domy, hodinové hotely, herne, polosvet, prostitúcia, okultistické sekty, mesto občas sa zahalujúce do závoja utkaného z hmly a dažd'a, „melancholické mesto“ (Krajewski 2008: 59), podobne ako je melancholický pohlad kriminálneho radcu Eberharda Mocka (Krajewski 2008: 15). Kamila 
340 Augustyn dokonca píše, že v Krajewského detektívnom cykle sa presúva dominanta ,z fabuly a protagonistu na obraz mesta“ (Augustyn 2017 :197). Vo l'vovskej sérii o komisárovi Popielskom prevládajúci nočný čas deja Krajewski ešte navyše motivuje Popielského chorobou epilepsia photogenica - jeho precitlivenostou na denné svetlo, ktoré mu môže privodit' epileptický záchvat.

Vzt'ah žánru detektívky k istej mestskej metropole je v retrodetektívke vel'mi tesný. Tá je totiž - slovami Marcina Wrońského, autora lublinského cyklu retrodetektívok - „podžánrom do vel'kej miery historickým a topografickým“ (citované podla Mazurkiewicz 2014:162). Reprezentované obdobie sa v retrodetektívke zväčša viaže s konkrétnym mestom, ktoré je v Krajewského románoch iným, fantómovým dvojníkom súčasného mesta - „potomka“: nemecký Breslau do roku 1945 s nemeckými toponymami. Romány z breslauskej série v prvom vydaní, od druhej knihy vychádzajúce vo vydavatel'stve WAB v edícii Temná séria (Mroczna seria), vždy sprevádzala mapa mesta z daného historického obdobia s nemeckými názvami ulíc a dobová fotografia temnej uličky na obálke. V druhej sérii o inšpektorovi Popielskom je zasa takýmto fantómovým mestom stratené mesto, pol'ský L'vov (metropola Haliče L'vov oproti neskoršiemu sovietskemu a ukrajinskému L'vovu): v oboch prípadoch ide o mestá-semiosféry, ktoré dnes už neexistujú. Breslau a Vroclav - ten istý fyzický priestor, ale iné (kultúrno-historické) svety, predelené radikálnou hranicou - presídlením pôvodného obyvatel'stva a prílevom nového, tiež presídleného.

V debute Smrt'v Breslau vovádza Krajewski svojho pol'ského čitatela do neznámeho nemeckého mesta (porovnaj Augustyn 2017: 186). Nemecký Breslau nebol pre jeho následných „dedičov“, obyvatel'ov pol'ského Vroclavu, vel'mi známy (porovnaj Gemra 2013: 126). Už samotné iné meno mesta je nositelom významov - meno mesta je „zašifrovanou, ,zavinutou' fabulou“ (Koschany 2013: 112), ktorá odkazuje na text historickej encyklopédie. Breslau je fantómom minulosti súčasného Vroclavu aj fyzicky: $v$ roku 1945 bolo zničených sedemdesiat percent budov mesta (Gemra 2013: 127). Stopy po nemeckej, breslauskej minulosti Vroclavu sa M. Krajewskému pri mestských praktikách (de Certeau), akou je chôdza mestom, zjavovali ako staršia vrstva palimpsestu, akoby pod prítomným mestom bolo skryté fantomatické „druhé mesto“-napríklad reklamné nápisy švabachom, ktoré sa objavovali pod opadávajúcou omietkou, či nemecké nápisy na potrubiach kanalizácie (porovnaj Gemra 2013: 127). Prítomnost' mestského priestoru totiž „kondenzuje predchádzajúce obdobia“ (Mongin 2014: 49). Práve v tomto fenoméne môžeme vidiet' ono tesné prepojenie času (retro) a priestoru (mesta) v žánri retrodetektívky: Michel de Certeau píše, že „miesta sú fragmentárnymi a zavinutými históriami, minulostami pozbavenými čitatelnosti inými, skumulovanými časmi, ktoré sa môžu rozvinút', ale ktoré tu vystupujú skôr ako potenciálne príbehy, záhady na rozlúštenie“ (de Certeau 2008: 109). M. Krajewski svojím aktom reprezentácie Breslau odvíja tieto príbehy minulosti, zavinuté v topografických miestach, vyvoláva duchov minulosti (miesto podla de Certeaua jestvuje natolko, nakol'ko je navštevované duchmi) (porovnaj de Certeau 2008: 109). Duchov minulosti je možné chápat' od prípadu k prípadu metaforicky alebo doslovne. Kompozícia väčšiny Krajewského retrodetektívok je rámcová: začiatok i koniec sa odohrávajú v neskoršom období. To im umožňuje obe historické podoby mesta geograficky prepojit' poukázaním na to, že ide o totožný fyzický priestor. Napríklad 
v románe Pevnost'Breslau Krajewski prostredníctvom naratívneho rámca, ktorý sa odohráva vo Vroclave v roku 1950, prepája dve neblahé historické obdobia (a dve toponymá) v jednom fyzickom mieste, zlopovestnej budove, kam sa „odkladajú“ „nepriatelia ludovej vlády, ktorými kapitán Baniakzaplńal kazematy bývalého sídla gestapa pri staromestskej priekope“ (Krajewski 2009: 11).

V psychológii obyvatel'ov pol'ského Vroclavu však toto mesto nikdy nebolo celkom ich (boli to vyst'ahovalci predovšetkým z-predtým pol'ského-L'vova), nebývali vo svojom a trýznili ich obavy, že sa „domáci“ raz vrátia a oni budú musiet' svoje domovy opustit', tak ako sa im to stalo už aj predtým (porovnaj Gemra 2013 : 128). Olivier Mongin píše, že mesto existuje, ,když se jednotlivcům podaří vytvořit dočasné vztahy v singulárním prostoru a když se považují za obyvatele města“" (Mongin 2017:47). Viacerí l'udia žijúci vo Vroclave podl'a vyššie uvedeného zrejme nezískali pocit domova v meste, v ktorom žili - v tomto zmysle vzniklo mesto nekompletné, akoby zmrzačené. Tým, že Krajewski použil v názve svojho cyklu meno Breslau, vo vnímaní pol'ských čitatel'ov vyvolal „mesto-prízrak“, symbol nie celkom akceptovanej minulosti (Gemra 2013: 130). Kolektívna identita obyvatel'ov mesta sa tak stáva otáznou - otázka, kto má právo povedat', „toto je moje mesto“, a kto sa s mestom dokáže vnútorne stotožnit' ako jeho obyvatel'. Marc Augé dokonca píše, že mesto má istú osobnost' a kolektívna identifikácia obyvatel'ov s mestom súvisí s touto osobnostou: „město má dějiny a osobnost: někteří jednotlivci se v něm poznávají a tato kolektivní identifikace (která může dojít až k určení psychologickými vlastnostmi sdílenými všemi obyvateli) není v rozporu s konkrétními vztahy, které může mít k městu každý člověk“ (Auge 1999: 111). Pomenovanie mesta je tiež, ako upozornil Michał Głowiński, symbolickým ovládnutím priestoru (Gemra 2013: 131). Kontinuitu oboch podôb mesta však Krajewski zaistuje tým, že v prvých troch románoch série už pri časovom a miestnom situovaní každej kapitoly označuje mesto z roku 1933, 1927 a 1919 ako Vroclav (i ked' fakticky nieslo meno Breslau). Anna Gemra upozorňuje, že toto používanie toponyma Vroclav na označenie mesta v „breslauskom“období „spôsobuje, že sa môžeme cítit' ako v okupovanom meste“ (Gemra 2013: 142). Fakticky sa v historickom období 1918 - 1945 v meste brutálne presadzoval nemecký živel (Davies - Moorhouse 2006: 374).

Pocit fantómového mesta, zvláštnej cudzosti domáceho, dotvárajú u pol'ských čitatel'ov tiež už nejestvujúce budovy (porovnaj Gemra 2013: 135) a dezorientácia vinou breslauských nemeckých toponým - iné mená tých istých ulíc, námestí a budov, ktoré vroclavský čitatel' zväčša nemusí byt' schopný prirad'ovat' k ich vroclavským ekvivalentom: jeho vlastné mesto sa takto odrazu stáva „cudzím priestorom“ (Gemra 2013: 130). Zároveň však niektoré toponymá ako Tumský most, Piaskowy most či Tumský ostrov sú aj toponymami dnešného Vroclavu. Túto dezorientáciu a „odcudzenie“ vlastného mesta paradoxne ešte zintenzívňuje Krajewského „takpovediac kartografická presnost““ (Augustyn 2017:186). Pravdepodobne to bola Krajewského zámerná stratégia - až v biografickej sérii Mock začal Krajewski k nemeckým toponymám v poznámkach pod čiarou prirad'ovat' ich pol'ských „dvojníkov“. Silné ukotvenie v toponymách, ich kumulácia a sprievodná mapa majú pre čitatela aj autentifikačnú a evokačnú funkciu a produkujú efekt reality.

V prípade Krajewského cyklu ide teda aj o obnovenie mesta vytesneného z kultúrnej pamäti. A. Gemra píše, že názov „Breslau“ patril v pol'skej povojnovej 
342 literatúre k zakázaným: „Píšuc o meste, nesmelo sa používat' meno Breslau, muselo sa zdôrazňovat', že bolo vždy piastovské, a teda - podl'a niektorých historikov - jednoznačne pol'ské, ,znovunadobudnuté, práve preto sa spolu so Západnými územiami ${ }^{1}$,vrátilo naspät' vlasti'“ (Gemra 2013: 127). Hovorilo sa o „znovuzískaných územiach“ (Ziemie Odzyskane) a do bývalého Breslau, teraz ruín Vroclavu, prichádzali „pionieri“, bývalí pol'skí obyvatelia L'vova.

M. Krajewski neskôr v románe Rieky Hádesu (2012) uviedol na scénu aj pokračovanie tohto diskontinuitného príbehu mesta Breslau/Vroclav, ked' dej svojho románu situoval do obdobia povojnového rodiaceho sa pol'ského mesta Vroclav v roku 1946 - spáleného mesta, vstávajúceho z popola. Hrdinom je, príznačne, nie breslauský Nemec Mock, ale Poliak, suspendovaný komisár Popielski, pristahovalec z L'vova. Menia sa teda toponymá mesta, národne aj ideologicky - železničná stanica Nadodrze, Trzebnická ulica, Słowiańska ulica, námestie Vel'kopol'ských povstalcov, severná štvrt' Kleczków, Stalinova ulica a iné. Pribúdajú pol'ské vývesné štíty na obchodoch. Synekdochicky „prevzatie“ mesta ukazuje Krajewski na budove kostolíka sv. Idziego, kde nová moc chce historicky legitimizovat' svoj územný nárok na mesto: „prikázali z neho otĺct'a strhnút' barokovú omietku a ornamenty, aby sa prekopali k románskym, stredovekým, a teda pol'sko-piastovským vrstvám, a na jeho príklade ukázali, že vo Vroclave ,kamene hovoria po pol'sky“" (Krajewski 2012: 53).

Obraz mesta sa tu príznačne začína výhl'adom z okna väzenia na čerň neba nad Vroclavom: „Kontrast, ktorý vyrezával predmety v ponurom prísvite, bol zo začiatku neostry" (Krajewski 2012:17). Ruiny mesta, vypálené domy a niektoré zachované štvrte, zablatené trhovisko, škaredé bytovky - „ponuré mesto“ (Krajewski 2012: 27) s potkanmi vyliezajúcimi v noci z pivníc, to všetko vytvára obraz zmaru, deštrukcie a depresie: je to hriešne mesto na iný spôsob než predchádzajúci dekadentný Breslau. Aj toto mesto má svoj polosvet a Krajewski načrtáva jeho topografiu. Popielskému zruinovaný Vroclav, v ktorom je nútený žit' a skrývat' sa, kontrastuje so strateným mestom L'vov a so stratenými „zlatými časmi“: „Zabrali nášśvov, a toto mesto, ktoré sami zničili, nám podhodili ako žvanec!" (Krajewski 2012: 26).

V opačnej tendencii voči mestu Breslau ako fantomatickému ,odcudzenému“ mestu však pôsobí samotné toponymické ukotvenie - vztah ku geografickému priestoru, vykračujúcemu „za“ román. Ako ukazujú výskumy pol'skej geopoetiky, autentické toponymá sú síce podla Tomasza Derlatku „predovšetkým súčastou textu (štruktúry textu)“ (citované podla Rybicka 2014: 186), ich pozícia v tejto štruktúre (napríklad románu) je však iná než pozícia ostatných jazykových prvkov literárneho textu: napríklad pozícia toponým v kultúrnej encyklopédii je iná ako pozícia názvov fikčných miest a postáv. Toponymá zakomponované do literárneho textu tvoria „trhlinu a pretrhávajú kontinuum predstaveného sveta“ (Rybicka 2014: 188). Pre geopoetiku tvoria „spojivo či médium interakcie a cirkulácie medzi literatúrou a geografickým priestorom“ (Rybicka 2014:188). Podla Briana McHalea sú do fikcie „zapájané“ a „vytvárajú enklávy ontologickej diferencie vnútri fikčného heterokozmu“ (Rybicka 2014: 188). Ich signifikácia je teda dvojsmerná, vztahujú sa zároveň k internej štruktúre textu, do ktorého sú zapojené,

1 „Ziemie Zachodnie“, neskôr nazývané „Ziemie Odzyskane“ - územia, ktoré na základe rozhodnutí Postupimskej konferencie pripadli po druhej svetovej vojne Pol'sku. 
no aj k vonkajšiemu geografickému miestu ako kultúrnemu i fyzickému objektu. 343 Elżbieta Rybicka tu používa termín toponomastického trópu: „Autentické vlastné mená v literatúre fungujú totiž ako toponomastické trópy, majú jazykový charakter, tvoria integrálnu súčast' výpovede, spoluvytvárajú jej sémantiku, no zároveň túto integrálnost' narúšajú, ked'odkazujú na vonkajšie referenčné pole“ (Rybicka 2014: 188). Vzhl'adom na túto svoju dvojitú referenciu, fikčnú i empirickú, je ich modelovým trópom syllepsa (Rybicka 2014: 192).

Príkladom reálnych dôsledkov toponomastickej syllepsy breslauského cyklu M. Krajewského je napríklad kultúrna praktika, akou je turistická výprava Vroclavom po stopách fikčnej postavy detektíva Edberharda Mocka, pričom turista sa môže zúčastnit inscenovania scén z románov M. Krajewského (porovnaj Rybicka 2014: 208). V článku Agnieszky Bieleckej Prechádzka kriminálnou stopou Eberharda Mocka si záujemca môže pozriet' fotografie dôležitých budov miesta deja z mockovského cyklu ako napríklad mamutiu hnedastú, rešpekt vzbudzujúcu budovu Policajného prezídia, mestské kúpele, Univerzitnú knižnicu na Piasku, secesný obchodný dom bratov Baraschovcov, dom Pod Gryfami aj spolu s mapkou (porovnaj Bielecka: 2018). Pre toto zvláštne spojenie fikcie a reality, napríklad pre spojenie konania fikčných postáv s reálnymi miestami, akým je odohrávanie sa fikčných udalostí na reálnych miestach, vytvoril Stijn Reijnders termín miesta imaginácie, „na ktorých sa prekračuje symbolická hranica medzi ,vyfantazírovaným' a ,reálnym' svetom“ (citované podl'a Rybicka 2014: 208-209): Holmesov byt na Baker Street, dom, v ktorom býval Raskol'nikov, a rovnako aj Mockov Breslau. Ak sú v niektorých textoch takéto toponomastické syllepsy zašifrované, môže hl'adanie týchto zamaskovaných fikčných miest v reálnom geografickom priestore prinášat aj vzrušujúce dobrodružstvo. Napríklad pol'ský spisovatel' Zbigniew Nienacki vo svojom kultovom dobrodružno-detektívnom cykle románov pre mládež o amatérskom detektívovi pánovi Tragáčikovi situoval drvivú väčšinu svojich literárnych miest v reálnych geografických súradniciach, na reálnych fyzických, topograficky určených miestach i v reálnych budovách, no niektoré miesta zašifroval (porovnaj Roszewski 2020).

\section{Reprezentácia všednosti v retro mode}

Akým spôsobom, akými jazykovými (rétorickými) stratégiami je mesto reprezentované v literárnom texte? Kamila Augustyn rozlišuje predovšetkým dva typy charakteristík: reálne a abstraktno-vztahové. Reálne charakteristiky sa vztahujú $\mathrm{k}$ dobovým reáliám, ku konkrétnym miestam a k objektom (ulice, budovy) i k lúd'om v meste, abstraktno-vztahové (symbolické) charakteristiky sú zasa metaforami či personifikáciami mesta, psychickými i psychofyzickými stavmi postáv ako napríklad pocit prináležitosti k mestu, charakteristiky vytvárajúce atmosféru mesta a podobne (porovnaj Augustyn 2017: 13, 201-202, 221). Na konkrétnej úrovni Krajewského text vytvára reprezentáciu dobového mesta synekdochickým spôsobom opisu, vŕšením konkrétnych „retro“ detailov, do ktorého votkáva toponymá, čím detaily neustále kartograficky situuje (na „mape“ mesta). Tieto opisné detaily sú narativizované priestorovou praktikou prechádzania mestom - v nižšie uvedenom príklade jazdou autom (dobovým Adlerom). Opisné detaily sú zasadené do „priestorovej syntaxe“ (de Certeau 2008:115), čím sa narativizujú - „deskriptory trasy“ dominujú v „naratívnom tkanive“ (de Certeau 2008: 119). 
344 Rozprávania - príbehy totiž „prechádzajú a organizujú miesta, vyberajú ich a spájajú, tvoria z nich vety a trate. Sú priestorovými trasami“ (de Certeau 2008: 115).

„Prichádzali na Sonnenplatz. [...] V zákrute zaškrípala električka vezúca robotnikov druhej zmeny z Linkeho, Hoffmannovej a Lauchhammerovej továrne, plynové lampy blikali. Zabočili doprava na Gartenstrasse: v tržnici sa tisli povozy dovážajúce zemiaky a kapustu, vrátnik secesnej budovy na rohu Theaterstrasse nadávajúc opravoval lampu pri bráne, dvaja opitíštudenti obtažovali prostitútky, ktorésa pyšne prechádzali so slnečníkmi okolo Koncertnej siene“" (Krajewski 2007: 14).

Mock premeriavajúci trasy po Breslau, zväčša pešo, niekedy autom, nie je, samozrejme, žiadny flanér -jeho trasa je vždy racionálne určená vyšetrovaním: cestou na miesto činu, cestou za podozrivými, napríklad do putiky, kde môže získat' informáciu a podobne. Práve tieto naratívne trasy s dobovými toponymami sú jednou z podstatných textových stratégií, ktoré v Krajewského románoch vytvárajú reprezentáciu Breslau. Spolu s touto stratégiou sa na reprezentácii podiel'a stratégia rozosievania dobových reálií v texte, keď̌e, ako píše de Certeau, „rozprávania o miestach sú brikoláže. Sú zhotovené zo zvyškov sveta“" (de Certeau 2008: 108). Plynové lampy, meissenský („míšeňský“) porcelán, taburet, plechové umývadlo, pohovka chaissez-longue, neoklasicistický nábytok od Bonzaniho, gymnaziálne uniformy „študentiek“ (v skutočnosti mladých prostitútok), revolvery Walther a Glock, značky automobilov Adler a Horch, drožky so zapriahnutými koňmi, prášok na čistenie zubov, pipasár fajky... Ako upozornila Martyna Steckiewicz, „historické reálie sú viditel'né skôr v každodennom živote hrdinov“ (Steckiewicz 2014: 251). Sú to detaily všedného života: aké noviny sa vtedy čítali, drožky či značky áut, dobové jedálne lístky v reštauráciách - to všetko sú rekvizity retrosveta.

Breslau teda nie je v Krajewského sérii detektívnych trilerov o Eberhardovi Mockovi iba pozadím, motivickým „plánom prostredia“, ale aj „miestom vytvárania kultúrnych významov“ (Augustyn 2017: 12), čo je už jeho abstraktno-symbolická reprezentácia. V poradí druhý román mockovskej série Koniec sveta v Breslau (Koniec świata w Breslau, 2003) svojím názvom Breslau istým spôsobom mýtizuje v synekdochickom režime: svet je celok, Breslau je jeho čast' - a koniec tohto celku sa udeje práve v tej jeho časti, ktorou je Breslau. Hra o osud celého sveta sa rozohrá v meste Breslau. $\mathrm{V}$ závere príbehu sa práve v Breslau odohrá „,demonštrácia zla“, zjavenie diabla. Krajewski pri kreovaní svojho literárneho Breslau často využíva estetiku turpizmu (z latinského turpis - škaredý, ohyzdný), kult ošklivého a hnusu (v pol'skej literatúre sa objavil po roku 1956 napríklad v poézii Stanisława Grochowiaka) - popri opisoch umučených, nezriedka rozporciovaných a rozkladajúcich sa mŕtvol obetí sú to špinavé zadné dvorčeky, dobová „hygiena“ či zápach pitevne, ktorý Mockovi opakovane pripomína pach dusenej mrkvy. Čitatel'ovi text takto pomocou odvolania sa na pravdepodobne známy čuchový vnem dokáže pach pitevne neprijemne, až nechutne evokovat'. Zároveň sa prostredníctvom pachu „nechutne“ dostávajú do asociačnej blízkosti mŕtve telo a jedenie. Časté býva fyzické znetvorenie postáv.

\section{Naratívna reprezentácia mesta: mesto ako príbeh}

O. Mongin hovorí o jednej z dimenzií mesta - o meste ako príbehu. „Město, duševní obraz, je dobrodružstvím, které se bez ustání utváří a přehrává. Od té chvíle, co 
obsahuje čas, se živí stejně tak kontinuitou jako diskontinuitou. Právě tak jako pří- 345 běh" (Mongin 2017:48).V analyzovanom prípade, ked'že ide o románové Breslau, to platí dvojnásobne: Krajewského mysteriózne retrodetektívky sú naratívnou reprezentáciou mesta Breslau. Krajewského Breslau je „rozprávaným“ literárnym mestom, časopriestorom v literárnych textoch, časopriestorom, v ktorom prebiehajú udalosti a zauzl'ujú i rozuzlujú sa zápletky, „,svetom príbehu“- neustále sa navršujúcimi príbehmi, ktoré ho v románovej sérii literárne konštituujú. Sú to príbehy násilia, zločinov a ich vyšetrovania, ako aj občasných udalostí na hrane nadprirodzena. $\mathrm{V}$ románoch série je časopriestor mesta prepojený s istým typom naratívnej schémy. Debut Smrt'v Breslau (1999) skonštruoval príbeh invázie z Orientu priamo do srdca sliezskej metropoly. Aj neznesitel'ná letná pál'ava v tomto príbehu akoby prichádzala stadial'. Táto invázia je priamo inscenovaná v scéne na mieste činu - v púštnych škorpiónoch vyliezajúcich z tela zavraždenej. Krajewski tu ako páchatel'a využíva topos pomstitel'ov z d'alekého Východu - teda topos detektívnej literatúry z 19. storočia, napríklad u Wilkieho Collinsa či Arthura Conana Doyla, ktorý bol v súlade s orientalistickými fantáziami tých čias. Ďalším príbehovým archetypom, ktorý Krajewski zakomponúva do zápletky, je oidipovský scenár.

Inú príbehovú schému využil Krajewski v nasledujúcom diele cyklu Koniec sveta v Breslau (2003). Mock tu porovnávaním vrážd v sérii vypátra, že vrah vyberá obete l'ubovol'ne, dôležité sú preňho čas (dátum) a miesto vraždy. Mock teda musí pri pátraní od perspektívy chodca (de Certeau) prejst' k perspektíve „projektanta“ mesta, z princípu trasy prejst' k princípu mapy (porovnaj de Certeau 2008: 118), povzniest' sa od konkrétneho žitého priestoru k jeho abstraktnej reprezentácii, mape: hl'adat' na mape vzorec spájajúci vraždy, neviditel'ný na konkrétnych miestach činu. Práve mapa, skonštituovaná v novoveku, abstraktná mapa ako „formálny súbor abstraktných miest“ (de Certeau 2008:120), ktorá sa už oslobodila od staršieho vyznačovania trás v stredovekých mapách (de Certeau 2008:120), umožňuje odhalit' skryté vzorce, ktoré nie sú bezprostredne viditel'né (porovnaj Moretti 2014:54).V inkriminovaných dňoch boli na daných miestach analogickým spôsobom spáchané vraždy v dávnej minulosti. Vraždy v sérii Kalendárového vraha takýmto spôsobom vlastne „citujú“ dávne vraždy z histórie mesta - ba ich čas, miesto a modus operandi sú mestom Breslau, jeho históriou priam generované. Ide tu teda naozaj o sériu topograficko-historických vrážd. Tento mestský pitaval, krvavo inscenovaný telami obetí, je spätý s (kriminálnou) históriou mesta, je jej „prekladom“ z análov zločinu do (fikčnej) reality. V sérii topograficko-historických vrážd je presne toto spojenie historického obdobia a topografie charakteristické pre žánrový variant retrodetektívky, ktorý je charakterizovaný práve časopriestorom, spájajúc priestor (mesto) a čas (historické obdobie). Krajewski v Konci sveta v Breslau vlastne touto zápletkou vydestiloval akúsi dreň žánrového variantu retrodetektívky, jeho základ.

Zasadenie deja do historického obdobia Festung Breslau v románe Pevnost'Breslau (Festung Breslau, 2006) umožňuje Krajewskému pri reprezentácii mesta rozvinút jeho infernálne atribúty, prechádzat' od konkrétnych charakteristík (reálií) z predchádzajúcich románov cyklu aj k občasným abstraktným reprezentáciám, napríklad personifikačnej, a prepájat' ich: ked' Mock vo svojom byte na Zwingerplatzi pocíti slabú vibráciu podlahy, akú spôsobujú „detonácie striel, ktoré vrhali zo Schweidnitzer Vorstadt nebelwerfery smerom na juh, odkial' 
346 sa aziatské hordy dobýjali do pevnosti Breslau" (Krajewski 2009: 18) (čo je konkrétna charakteristika - toponymum a typ zbraní), „interpretoval ju ako jednu získal aj jeho pištol' pre svoje vojenské hry, je peklom.

Podl'a K. Augustyn je rozhodujúci práve význam, aký má mesto Breslau v Krajewského sérii, Krajewského prínosom do formuly detektívneho žánru: „Titulný Breslau je teda klúčom k interpretácii Krajewského diel. Vd'aka víziám mesta, úzko spätým s fabulačnou štruktúrou a ešte silnejšie s kreáciou postáv, predovšetkým s osobou hlavného hrdinu, sa Krajewskému darí prelomit žánrovú schému detektívneho románu“ (Augustyn 2017: 197). V niektorých prípadoch až natol'ko, že to má negatívny dopad aj na kvalitu riešenia detektívnej zápletky.

Analýza stratégií reprezentácie mesta v Krajewského breslauskom cykle ukázala, že tieto jednotlivé stratégie sa spájajú vždy s určitou vrstvou textovej štruktúry a na ich analýzu je vhodná vždy istá oblast' literárnej vedy. Topografická reprezentácia mesta prostredníctvom vrstvy minulých toponým a ich retazenia do trás vykračuje za striktne internú štruktúru textu a na ich analýzu je vhodná geopoetika. Stratégia reprezentácie všednosti prostredníctvom dobových reálií dennej potreby vytvára vrstvu žánru retro. Naratívna reprezentácia mesta - príbehy (a ich matrice), ktoré vytvárajú Krajewského literárne Breslau - konštituuje predovšetkým vrstvu žánru detektívneho trileru. Prepojenie týchto stratégií reprezentácie mesta, ktoré sme vydelili takpovediac priečnym rezom textového korpusu breslauského cyklu, vytvára Krajewského osobitú žánrovú reprezentáciu mesta. ${ }^{2}$

\section{Pramene}

KRAJEWSKI, Marek, 2007. Smrt'v Breslau. Jazykovo zmutoval Tomáš Horváth. Bratislava: Slovart. ISBN 978-80-8085-410-2.

KRAJEWSKI, Marek, 2008. Koniec sveta v Breslau. Jazykovo zmutoval Tomáš Horváth. Bratislava: Slovart. ISBN 978-80-8085-409-6.

KRAJEWSKI, Marek, 2009a. Prízrakyv Breslau. Jazykovo zmutoval Tomáš Horváth. Bratislava: Slovart. ISBN 978-80-8085-636-6.

KRAJEWSKI, Marek, 2009b. Pevnost'Breslau. Jazykovo zmutoval Tomáš Horváth. Bratislava: Slovart. ISBN 978-80-8085-732-5.

KRAJEWSKI, Marek, 2012. Rzeki Hadesu. Kraków: Wydawnictwo Znak. ISBN 978-83-240$-2239-7$.

\section{Literatúra}

AUGÉ, Marc, 1999. Antropologie současných světů. Přeložila Ivana Holzbachová. Brno: Atlantis. ISBN 80-7108-154-X.

AUGUSTYN, Kamila, 2017. Wroctaw. Literacka geografia miasta. Wrocław: Oficyna Wydawnicza ATUT. ISBN 978-83-7977-315-2.

CERTEAU de, Michel, 2008. Wynaleźć codzienność. Przekład Katarzyna Thiel-Jańczuk. Kraków: Wydawnictwo Uniwersytetu Jagiellońskiego. ISBN 978-83-233-2597-0.

2 Text bol pre potreby časopiseckého publikovania skrátený. 
DAVIES, Norman - MOORHOUSE, Roger, 2006. Mikrokosmos. Přeložila Petruška Šustrová. Praha: BB art. ISBN 80-7341-799-5.

DERDOWSKA, Joanna, 2011. Kmitavá mozaika. Př́ibram: Pistorius \& Olšanská. ISBN 978 -80-87053-57-7.

GEMRA, Anna, 2013. Eberhard Mock na tropie: Breslau/Wrocław w powieściach Marka Krajewskiego. In URSEL, Marian - TARANEK-WOLAŃSKA, Olga, ed. Śląskie pogranicza kultur. Tom 2. Wrocław: Oficyna Wydawnicza ATUT - Wrocławskie Wydawnictwo oświatowe, s. 119-143. ISBN 978-83-7432-989-7.

HALBWACHS, Maurice, 2009. Kolektivní pamět'. Přeložil Yasar Abu Gosh. Praha: SLON. ISBN 978-80-7419-016-2.

KOSCHANY, Rafał, 2013. Semiotyka miasta: od lektury „tekstu“ do interpretacji jako praktyki miejskiej. Studia Kulturoznawcze, nr. 1 (3), s. 109-124. ISSN 2084-2988.

MAZURKIEWICZ, Adam, 2014. Tendencje rozwojowe współczesnej polskiej literatury kryminalnej. In GEMRA, Anna, ed. Literatura kryminalna. Kraków: EMG, s. 151-176. ISBN 978-83-63464-60-8.

MONGIN, Olivier, 2017. Urbánnísituace. Město v čase globalizace. Přeložila Edita Wolf. Praha: Nakladatelství Karolinum. ISBN 978-80-246-3442-5.

MORETTI, Franco, 2014. Grafy, mapy, stromy. Přeložila Olga Čaplyginová. Praha: Nakladatelství Karolinum. ISBN 978-80-2462-609-3.

ROSZEWSKI, Emil, 2020. Na tropie Pana Samochodzika. Warszawa: Wydawnictwo CM. ISBN 978-83-66371-85-9.

RYBICKA, Elżbieta, 2014. Geopoetyka. Kraków: Universitas. ISBN 97883-242-2393-0.

STECKIEWICZ, Martyna, 2014. Czas przeszły dokonany? Obraz międzywojnia w kryminałach retro. In GEMRA, Anna, ed. Literatura kryminalna. Kraków: Wydawnictwo EMG, s. 247-261. ISBN 978-83-63464-60-8.

TOPOROW, Władimir, 2002. Przestrzeń i tekst. Przekład Bogusław Żyłko. Przestrzenie teorii, roč. 1, č. 1, s. 207-223. ISSN 1644-6763.

WRÓBLEWSKA, Violetta, 2014. Gatunkowy synkretyzm czy eklektyzm? O nowej formule polskiego kryminału po 1989 roku. In GEMRA, Anna, ed. Literatura kryminalna. Kraków: Wydawnictwo EMG, s. 129-150. ISBN 978-83-63464-60-8.

ŻYŁKO, Bogusław, 2007. Miasto jako przedmiot semiotyki kultury. Estetyka i Krytyka, vol. 12, nr. 1, s. 65-72. ISSN 2353-723X.

\section{Internetové zdroje}

BIELECKA, Agnieszka, 2018. Spacer kryminalnym szlakiem Eberharda Mocka. 15. 9. 2020. https://kochamwroclaw.pl/spacer-sladem-eberharda-mocka-trakcie/

Mgr. Tomáš Horváth, PhD.

Ústav slovenskej literatúry SAV

Dúbravská cesta 9

84104 Bratislava

Slovenská republika

E-mail: tomas.horvath@savba.sk 